\title{
Chemical and physical characteristics of aerosol particles at a remote coastal location, Mace Head, Ireland, during NAMBLEX
}

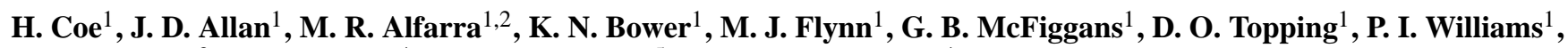 \\ C. D. O'Dowd ${ }^{3}$, M. Dall'Osto ${ }^{4}$, D. C. S. Beddows ${ }^{5}$, and R. M. Harrison ${ }^{4}$ \\ ${ }^{1}$ School of Earth, Atmospheric and Environmental Science, University of Manchester, Manchester, M60 1QD, UK \\ ${ }^{2}$ Paul Scherrer Institut, Laboratory of Atmospheric Chemistry, CH-5232, Villigen, PSI, Switzerland \\ ${ }^{3}$ Department of Physics, National University of Ireland, Galway, University Road, Galway, Ireland \\ ${ }^{4}$ University of Birmingham, Division of Environmental Health and Risk Management, Birmingham, UK \\ ${ }^{5}$ Department of Physics, University of Wales, Swansea, Singleton Park, Swansea, SA2 8PP, UK
}

Received: 18 October 2005 - Published in Atmos. Chem. Phys. Discuss.: 14 November 2005

Revised: 1 August 2006 - Accepted: 1 August 2006 - Published: 9 August 2006

\begin{abstract}
A suite of aerosol physical and chemical measurements were made at the Mace Head Atmospheric Research Station, Co. Galway, Ireland, a coastal site on the eastern seaboard of the north Atlantic Ocean during NAMBLEX. The data have been used in this paper to show that over a wide range of aerosol sizes there is no impact of the intertidal zone or the surf zone on measurements made at $7 \mathrm{~m}$ above ground level or higher. During the measurement period a range of air mass types were observed. During anticyclonic periods and conditions of continental outflow Aitken and accumulation mode were enhanced by a factor of 5 compared to the marine sector, whilst coarse mode particles were enhanced during westerly conditions. Baseline marine conditions were rarely met at Mace Head during NAMBLEX and high wind speeds were observed for brief periods only.

The NAMBLEX experiment focussed on a detailed assessment of photochemistry in the marine environment, investigating the linkage between the $\mathrm{HO}_{\mathrm{x}}$ and the halogen radical cycles. Heterogeneous losses are important in both these cycles. In this paper loss rates of gaseous species to aerosol surfaces were calculated for a range of uptake coefficients. Even when the accommodation coefficient is unity, lifetimes due to heterogeneous loss of less than $10 \mathrm{~s}$ were never observed and rarely were they less than $500 \mathrm{~s}$. Diffusional limitation to mass transfer is important in most conditions as the coarse mode is always significant. We calculate a minimum overestimate of $50 \%$ in the loss rate if this is neglected and so it should always be considered when calculating loss rates of gaseous species to particle surfaces. $\mathrm{HO}_{2}$ and $\mathrm{HOI}$ have accommodation coefficients of around 0.03 and hence we calculate lifetimes due to loss to particle surfaces of $2000 \mathrm{~s}$ or greater under the conditions experienced during NAMBLEX.
\end{abstract}

Correspondence to: $\mathrm{H}$. Coe

(hugh.coe@manchester.ac.uk)
Aerosol composition data collected during this experiment provide representative information on the input aerosol characteristics to western Europe. During NAMBLEX the submicron aerosol was predominately acidified sulphate and organic material, which was most likely internally mixed. The remaining accumulation mode aerosol was sea salt. The organic and sulphate fractions were approximately equally important, though the mass ratio varies considerably between air masses. Mass spectral fingerprints of the organic fraction in polluted conditions are similar to those observed at other locations that are characterised by aged continental aerosol. In marine conditions, the background input of both sulphate and organic aerosol into Europe was observed to be between 0.5 and $1 \mu \mathrm{g} \mathrm{m}^{-3}$. Key differences in the mass spectra were observed during the few clean periods but were insufficient to ascertain whether these changes reflect differences in the source fingerprint of the organic aerosol. The coarse mode was composed of sea salt and showed significant displacement of chloride by nitrate and to a lesser extent sulphate in polluted conditions.

\section{Introduction}

The standard picture of marine aerosols (Van Dingenen et al., 1995; Quinn et al., 1996) has been of a multi-modal distribution, with a fine (Aitken) mode from 20 to $100 \mathrm{~nm}$ and an accumulation mode between 100 and $500 \mathrm{~nm}$. Particles greater than $250 \mathrm{~nm}$ in (dry) diameter have tended to be thought of as primarily sea salt (Clarke et al., 1997) while smaller aerosol have been thought to be mainly composed of sulphates. Recent work (Nilsson et al., 2001; Geever et al., 2005) shows sea salt aerosol present below $100 \mathrm{~nm}$ and fluxes of particles as small as $10 \mathrm{~nm}$ being significant depending on sea state. It is known that both sulphate aerosol and sea-salt

Published by Copernicus GmbH on behalf of the European Geosciences Union. 
aerosol play a role in determining the droplet number in marine stratocumulus clouds (O'Dowd et al., 1997; Bower et al., 1999) and this is the key to understanding the first and second indirect effects in these clouds. However, this picture is oversimplified as the role of organic material has not been considered. The presence of significant concentrations of organic material in marine aerosols has been appreciated for several decades (Hoffman and Duce, 1976). Only recently has this organic content been identified as being biogenically derived (O'Dowd et al., 2004). O'Dowd et al report that during phytoplankton blooms in the North Atlantic, the organic content of the submicron marine aerosols could constitute up to $63 \%$ of the total mass of the particles. By contrast, the winter contribution (low phytoplankton biomass) to aerosol mass was no more than $15 \%$. These data strongly implicate phytoplankton as a critical determinant in the production of marine aerosols. The impact this material has on the cloudforming properties of these aerosol remains highly uncertain but as the authors point out may be substantial and is likely to be largest for the smaller particles. It is the flux of dissolved organic matter (Larsson and Hagström, 1982) and exopolymer (Grossart, 1999) to particulate organic matter in the surface micro-layer, which is hypothesised to contribute significantly to the organic matter mass in marine aerosols. Dall'Osto et al. (2005) have observed organic rich sea salt particles at Mace Head that are correlated with Magnesium, postulated by Prather et al. ${ }^{1}$ to be derived from chlorophyll in the sea surface microlayer.

Raes (1995) suggested that marine boundary layer sulphate may arise via the remote free troposphere where injections of marine sulphur gases have sufficient time to be oxidised at colder temperatures and particle surface losses will be much reduced. However, in the northern hemisphere anthropogenic sources of $\mathrm{SO}_{2}$ dominate: these include oxidation via $\mathrm{SO}_{2}$ emissions from shipping and sulphate advected from continental regions in the free troposphere and then mixed into the marine boundary layer (Dore et al., 2000). Anthropogenically derived aerosol contain significant organic material, which is most likely to be internally mixed with sulphate and may be transported significant distances when not lost through wet removal processes (Allan et al., 2004; de Gouw et al., 2005) and like the organic material in sea salt this will affect its cloud-forming properties.

In addition to increasing the albedo of the marine environment and influencing the cloud droplet number of marine stratocumulus clouds, aerosol particles provide significant sinks for many trace gas and radicals. Bloss et al. (2005) used a photochemical box model to show that whilst halogen oxides provide an important loss of $\mathrm{HO}_{2}$ in the marine boundary layer under low $\mathrm{NO}_{\mathrm{x}}$ conditions, aerosols are very significant. Haggerstone et al. (2005) showed that in

\footnotetext{
${ }^{1}$ Prather, K., Guazzotti, S., and Holecek, C.: Probing atmospheric aerosol sources and processing using single particle mass spectrometry, in preparation.
}

clean marine conditions the loss of $\mathrm{HO}_{2}$ is underestimated by nearly a factor of two if aerosol losses are not considered. Likewise, night-time radical losses are also controlled to a significant degree by aerosol particles. Carslaw et al. (1997) demonstrate that under moderate $\mathrm{NO}_{\mathrm{x}}$ concentrations the loss of $\mathrm{N}_{2} \mathrm{O}_{5}$ to aerosol surfaces can dominate the loss of $\mathrm{NO}_{3}$ and provides a significant loss route for oxidised nitrogen from the gas phase.

This paper presents measurements of the physical and chemical properties of aerosol during the North Atlantic Marine Boundary Layer EXperiment (NAMBLEX). For an overview of the experiment and a summary of the key findings the reader is referred to Heard et al. (2006). The influence of the coastline on the aerosol number and mass size distribution is examined using multi-height measurements as coastal stations are often seen as not being representative of the background marine environment. The measurements are used to identify loss rates of trace gases to particle surfaces as a function of accommodation coefficient and particle size, such heterogeneous losses are important in marine boundary layer chemistry and the approach discussed in general here has been applied widely during NAMBLEX by several authors (Haggerstone et al. (2005), Bloss et al. (2005), Sommariva et al. (2006) and Smith et al. (2006)). Both online and offline measurements of aerosol chemical composition are used to investigate the chemical composition of aerosol in the marine boundary layer on the western edge of Europe and explore the organic component of the aerosol in both polluted air transported over long distances and in clean air.

\section{Measurements and instrumentation}

Microphysical and chemical properties of aerosol particles were measured from 1 August 2002 until 31 August 2002 during the NAMBLEX experiment close to the shore laboratory of the Mace Head Atmospheric Research Station $\left(53^{\circ} 19^{\prime} 34^{\prime \prime} \mathrm{N}, 9^{\circ} 53^{\prime} 14^{\prime \prime} \mathrm{W}\right)$. The site is described in detail in O'Dowd et al. (2002a) and the NAMBLEX experiment is described more fully in Heard et al. (2006). The shore laboratory is $5 \mathrm{~m}$ above mean sea level and is a distance of around $50 \mathrm{~m}$ from the shore in wind directions from around $180^{\circ}$ to $330^{\circ}$. The terrain is mostly low lying and undulating, the soil is predominately peat covered in rough grasses with a significant amount of exposed granite rock.

Aerosol particle number size distributions from $3 \mathrm{~nm}$ to $20 \mu \mathrm{m}$ diameter were measured using a range of differential mobility and optical probes. An in situ forward scattering spectrometer probe (FSSP), (Baumgardner et al., 1985), was used to measure the particle number size distributions from 1 to $20 \mu \mathrm{m}$ diameter. The instrument was mounted $8 \mathrm{~m}$ above the ground at the shore laboratory and was rotated into wind. A large manifold, mounted to a tower was used to deliver ambient air to an air conditioned sea container that served as the main laboratory. The manifold sampled from one of 
Table 1. Statistics for wind speed, temperature, relative humidity and total particle number concentration greater than $3 \mathrm{~nm}$ diameter in the five sampling periods identified by Norton et al. (2006) and discussed in Sect. 3.

\begin{tabular}{|c|c|c|c|c|c|c|c|}
\hline Period & Parameter & 10 Percentile & 25 Percentile & median & mean & 75 percentile & 90 percentile \\
\hline Period 1 & Wind speed & 1.3 & 2.7 & 3.47 & 3.7 & 4.9 & 6.5 \\
\hline $1 / 8 / 2002$ & Temperature & 15.6 & 16.1 & 17.2 & 17.3 & 18.2 & 19.2 \\
\hline to & RH & 80.5 & 85.2 & 89.5 & 88.8 & 94.0 & 95.6 \\
\hline $5 / 8 / 2002$ & $\mathrm{CN}(>3 \mathrm{~nm})$ & 555 & 864 & 1615 & 2348 & 2446 & 5785 \\
\hline Period 2 & Wind speed & 3.6 & 5.0 & 7.21 & 7.3 & 9.3 & 11.7 \\
\hline $6 / 5 / 2002$ & Temperature & 12.8 & 13.5 & 14.4 & 14.25 & 14.9 & 15.9 \\
\hline to & RH & 71.2 & 79.0 & 86.7 & 85.6 & 93.9 & 97.0 \\
\hline $11 / 8 / 2002$ & $\mathrm{CN}(>3 \mathrm{~nm})$ & 119 & 251 & 489 & 1006 & 1056 & 1692 \\
\hline Period 3 & Wind Speed & 3.0 & 5.1 & 7.8 & 8.0 & 11.1 & 12.0 \\
\hline $12 / 8 / 2002$ & Temperature & 14.1 & 14.5 & 15.1 & 15.1 & 15.5 & 15.8 \\
\hline to & RH & 76.1 & 80.2 & 85.9 & 86.7 & 95.3 & 97.3 \\
\hline $17 / 8 / 2002$ & $\mathrm{CN}(>3 \mathrm{~nm})$ & 249 & 411 & 624 & 1382 & 939 & 2543 \\
\hline Period4 & Wind Speed & 1.5 & 2.6 & 3.8 & 4.0 & 5.4 & 6.4 \\
\hline $19 / 8 / 2002$ & Temperature & 13.5 & 14.6 & 15.5 & 15.1 & 15.9 & 16.3 \\
\hline to & RH & 74.6 & 79.4 & 86.3 & 85.4 & 91.4 & 95.8 \\
\hline $27 / 8 / 2002$ & $\mathrm{CN}(>3 \mathrm{~nm})$ & 394 & 561 & 870 & 1680 & 1331 & 4075 \\
\hline Period 5 & Wind speed & 4.4 & 6.6 & 8.12 & 8.3 & 9.6 & 12.2 \\
\hline $28 / 8 / 2002$ & Temperature & 14.1 & 15.3 & 15.7 & 15.6 & 16.3 & 16.5 \\
\hline to & RH & 79.5 & 83.7 & 91.3 & 89.5 & 96.8 & 97.8 \\
\hline $30 / 8 / 2002$ & $\mathrm{CN}(>3 \mathrm{~nm})$ & 161 & 219 & 331 & 454 & 482 & 645 \\
\hline
\end{tabular}

two heights above the ground, 7 and $22 \mathrm{~m}$, alternating on an hourly basis. An isokinetic sub-sampling pipe was fitted to the centre of the manifold at the height of the laboratory, distributing air to the instruments in the container. A particle counter (TSI 3025a) measured the total particle number concentration greater than $3 \mathrm{~nm}$ diameter and a Differential Mobility Particle Sizing system (DMPS) was used to measure the number size distribution of particles with diameters between 3 and $750 \mathrm{~nm}$. The DMPS was built to the Vienna design (Winklmayr et al., 1991) and is described in Williams et al. (2000) and more fully in Williams (1999). The DMPS comprised two differential mobility analysers, the smaller of the two was run with an aerosol flow of $1.5 \mathrm{lpm}$ and a sheath flow of $15 \mathrm{lpm}$, the larger DMA was run with flows of 1 and $10 \mathrm{lpm}$ respectively. Both DMAs sampled dry aerosol and their sheath air lines were run as an open system with a relative humidity below $5 \%$. These instruments were mounted close to the throat of the main sub sample pipe to minimise diffusional losses of small particles. Size distribution measurements presented in this paper are at ambient relative humidity, calculated from composition estimates using simple chemical volume mixing rule approximations.

The dimensions and flow rates of the sampling system were designed to minimise diffusional losses. A particle counter (TSI 3025) and a Scanning Mobility Particle Sizer (SMPS) were run adjacent to the throat of the $22 \mathrm{~m}$ manifold inlet for a day and found to agree with the 3025a and the DMPS sampling through the inlet system to within the instrument uncertainties confirming the particle loss calculations. An optical particle counter (GRIMM 1.105) measured the particle number distribution for particle diameters between $450 \mathrm{~nm}$ and $6500 \mathrm{~nm}$ from the manifold.

An Aerodyne Aerosol Mass Spectrometer (AMS) system sampled through the main manifold and was used to determine the composition of the non refractory, non sea salt component of the submicron aerosol. The instrument is described in Jayne et al. (2000), whilst details of the data analysis procedures and error analysis are detailed in Jimenez et al. (2003) and Allan et al. (2003). The AMS sampled throughout the month of August 2002 during NAMBLEX. However, due to an instrument failure the data available from $13 \mathrm{Au}-$ gust until 19 August, covering most of period 3, have considerably larger uncertainties.

An Aerosol Time Of Flight Mass Spectrometer (ATOFMS - TSI 3800) also sampled from the manifold. Data from this instrument is described in Dall'Osto et al. (2004) and a comparison between the AMS and the ATOFMS is described in Dall'Osto et al. (2005). An eight stage Micro-Orifice Uni- 

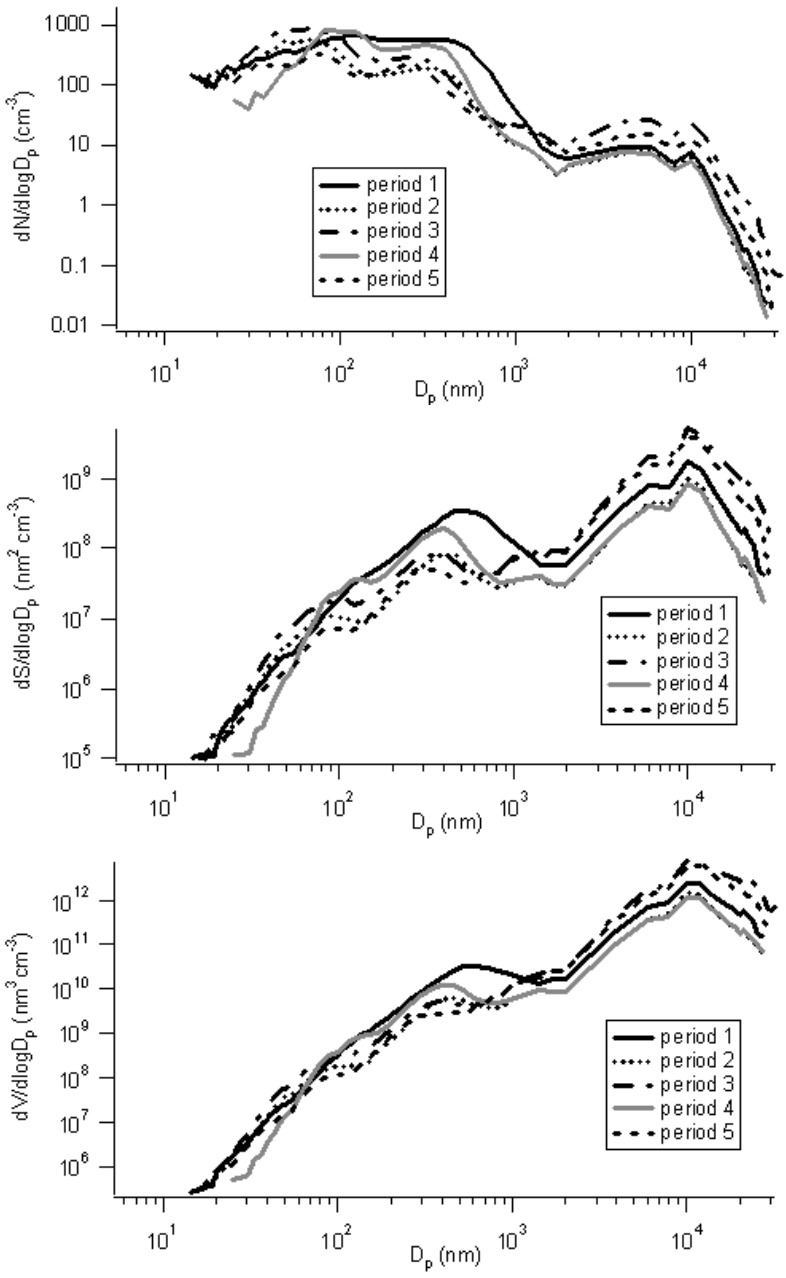

Fig. 1. Median number (a), surface area (b) and volume distributions (c) for each of the five sampling periods. Aerosol data presented at ambient humidity.

form Deposit Impactor (MOUDI) was used to sample aerosol particles onto substrates for subsequent analysis by ion chromatography for $\mathrm{Na}^{+}, \mathrm{K}^{+}, \mathrm{Mg}^{2+}, \mathrm{NH}_{4}^{+}, \mathrm{SO}_{4}^{2-}, \mathrm{NO}_{3}^{-}, \mathrm{Cl}^{-}$. Collections took place between 11 August 2002 and $22 \mathrm{Au}-$ gust 2002, each sample period running from 11:00 UT for $24 \mathrm{~h}$. The National University of Ireland, Galway, continuously operate a Magee aethalometer model AE-9. This instrument, together with the wind direction, has often been used to identify the clean air sector at the research station (Jennings et al., 1997). The criteria used here are similar to those applied by O'Dowd et al. (2004) and are restricted to those periods when the aerosol absorption is less than 0.475 $\mathrm{Mm}^{-1}$, and the wind direction is to the west and south of $180^{\circ}$ and $330^{\circ}$ respectively. The absorption coefficient is equivalent to a black carbon concentration of $25 \mathrm{ng} \mathrm{m}^{-3}$, calculated using an instrumental attenuation cross section value of $19 \mathrm{~m}^{2} \mathrm{~g}^{-3}$.

\section{Meteorological and physical properties of aerosol as a function of airmass}

Norton et al. (2006) provided a detailed meteorological characterisation during the NAMBLEX experiment based on local wind data, radar, balloon ascents and ECMWF model products. They identified 5 main periods during August 2002. Statistics showing the main characteristics of the local wind speed, temperature, relative humidity and particle number concentration greater than $3 \mathrm{~nm}$ during each of these periods are presented in Table 1 . Only a brief summary of that provided in Norton et al. (2006) is given here. Period 1 ran from 1 August to 5 August and could be identified by a semi-permanent decoupling of the surface layer from the mixed boundary layer above arising from a characteristic sea breeze development on most days, whilst the winds aloft were generally from the northeast. As Table 1 shows, the winds were very light and the temperatures were high and the air humid for much of the time. The particle counts show this period was comparatively polluted with a median particle concentration of $1600 \mathrm{~cm}^{-3}$. The air was identified as being from the clean sector only $2.5 \%$ of the time during this period.

Period 2 began after the passage of an occluded front on the 5 August and experienced westerly or north-westerly winds. There is some evidence of local influence on the wind profile during this period but the surface winds were similar to those aloft and Mace Head was exposed to the clean sector for $47 \%$ of the time. On the 8 August a depression tracked directly over the site and the winds shifted round $360^{\circ}$ though there was little evidence of land influences during the brief period of offshore wind.

During period 3 several frontal systems tracked over Mace Head delivering significant precipitation on most days. The wind direction remained westerly throughout this period both at the surface and aloft and the boundary layer appeared to be coupled for much of the time. This period gave rise to periods of enhanced wind speed, reaching a maximum of $20 \mathrm{~m} \mathrm{~s}^{-1}$ on the 17 August. Wind speeds On the 14 and 15 also exceeded $15 \mathrm{~m} \mathrm{~s}^{-1}$ for much of the day. Like periods 2 and 5, this period shows low particle number concentrations for much of the time. Clean air was observed $29 \%$ of the time, mostly in the day, at night the surface air was often decoupled below strong inversions.

An anticyclone developed during period 4 from $19 \mathrm{Au}-$ gust to 27 August with light winds. Sea breezes were observed from the 18 to 20 August and again on the 25 August. Though the wind direction was from the marine sector for much of the time, the sea breeze circulation regularly introduced polluted air and the clean sector criteria were only met $30 \%$ of the time. In the final period between the 28 and 30 August the wind was predominately westerly and well coupled at all levels. The clean sector criteria were met $76 \%$ of the time during this period. 


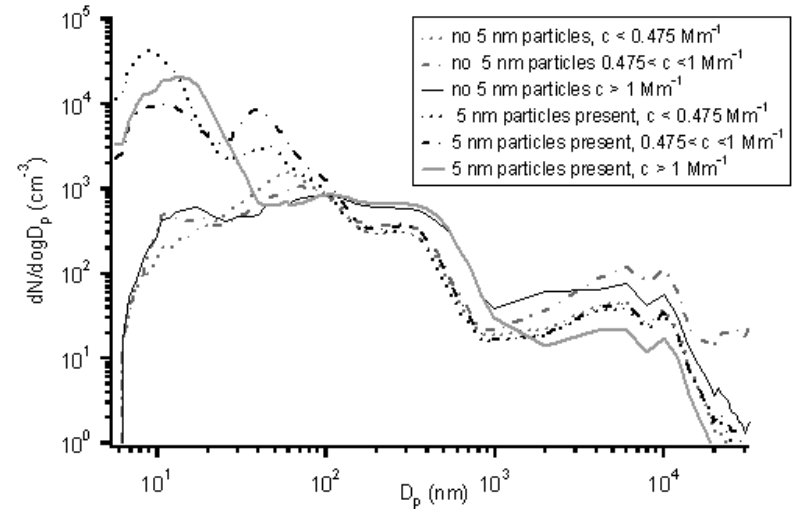

Fig. 2. Average number size distributions separated as a function of attenuation coefficient, $c$. The value of $0.475 \mathrm{Mm}^{-1}$ represents the identified clean air sector threshold used by O'Dowd et al. (2004) and periods of nucleation around low tide are considered separately to the remainder of the data.

The Aitken and accumulation modes in the median number size distributions observed during the marine, predominately cyclonic, periods ( 3 and 5) were lower than those observed in the more polluted, anticyclonic periods by approximately a factor of 5 and the coarse mode particle number was enhanced by approximately the same ratio (see Fig. 1). In the same figure, the surface area distribution can be seen to have been approximately equally composed of sub and supermicron aerosol. The volume distribution was heavily skewed to the coarse mode as might be expected from a relative clean marine environment. Enhancements in the coarse aerosol mode were from sea spray generation when the wind speeds were significantly above $10 \mathrm{~m} \mathrm{~s}^{-1}$, which occurred only $14 \%$ of the time and only on the days 11,14-15, 17 and 30 August 2002.

Attenuation coefficients measured by the aethelometer were used to separate aerosol sampled in clean and polluted periods once periods of new particle formation were separated from times when no ultrafine particles were observed in the lowest channels of the DMPS (Fig. 2). There is clear evidence of new particle formation and the existence of an ultrafine mode extending to around $20 \mathrm{~nm}$ in all conditions as has been seen previously, with the mode extending to slightly larger sizes in polluted conditions. Most likely this is due to the inter-tidal source of the precursors being further from the measuring site in easterly winds typical during polluted conditions rather than significant addition of anthropogenic secondary aerosol material being formed. There are differences in the accumulation and upper Aitken mode for attenuation coefficients below $1 \mathrm{Mm}^{-1}$. Above $1 \mathrm{Mm}^{-1}$ the air is considerably polluted and the accumulation mode size distribution is enhanced, broadens considerably, and displays a shape more characteristic of that of a rural continental aerosol. High winds were not observed during NAMBLEX

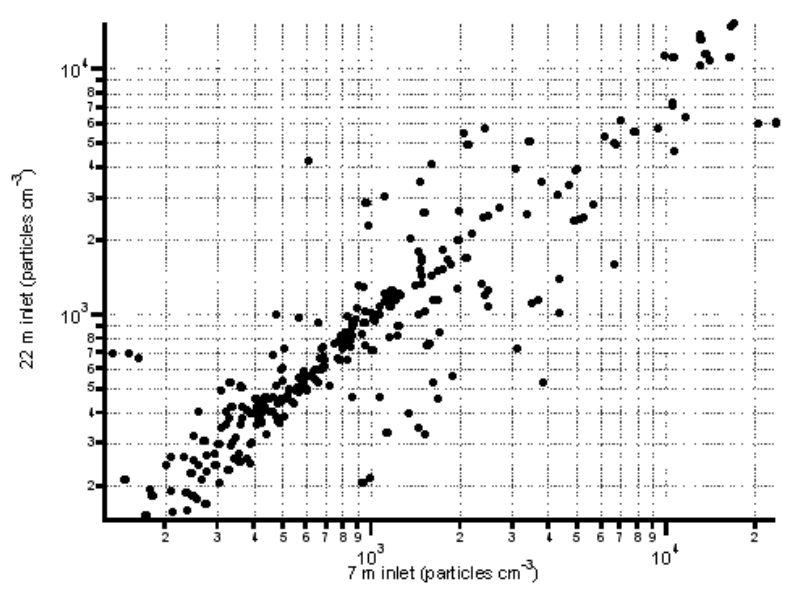

Fig. 3. Correlation between total particle number concentration greater than $3 \mathrm{~nm}$ diameter measured from the $22 \mathrm{~m}$ inlet and the $7 \mathrm{~m}$ inlet. The data were sampled alternately through each inlet on an hourly basis and each data point represents a running average over three cycles.

and the clean sector identified by O'Dowd et al. (2004) was rarely sampled for continuous periods. As a result the very high coarse mode sea spray aerosol loadings observed by O'Dowd et al. (2001) were not seen and the loadings are highly variable and independent of the pollution conditions.

\section{Coastal influences on aerosol particles at Mace Head}

Coastal monitoring stations, such as Mace Head, provide extremely important sampling locations for investigating the marine atmosphere and long range transport of pollutants, and in the case of Mace Head offer important baseline information. However, the coastal zone can have a significant influence on the particle size distribution in the near shore surface layer. New particle formation has been observed regularly during low tide at Mace Head (O'Dowd et al., 1999) and has been linked to polymerisation reactions of oxidised iodine, the precursors of which appear to be emitted from the large exposed beds of macroalgae (McFiggans et al., 2004; O'Dowd et al., 2002). The surf zone at the shore provides a large source of coarse mode particles, greatly enhancing the total surface area and volume of the particle population (de Leeuw et al., 2002; Kunz et al., 2002). Norton et al. (2006) have shown that the change in wind stress induced by the change in surface roughness at the shore propagates to a height of between 10 and $15 \mathrm{~m}$ at the sample site in all marine wind sectors and tidal states sampled. Hence all shore induced effects on the aerosol particle population at the sampling site will be restricted to heights below $15 \mathrm{~m}$.

In this paper, the effect of the tidal zone on the particle population was studied using the switching inlet system. Figure 3 shows the correlation between the total particle number 


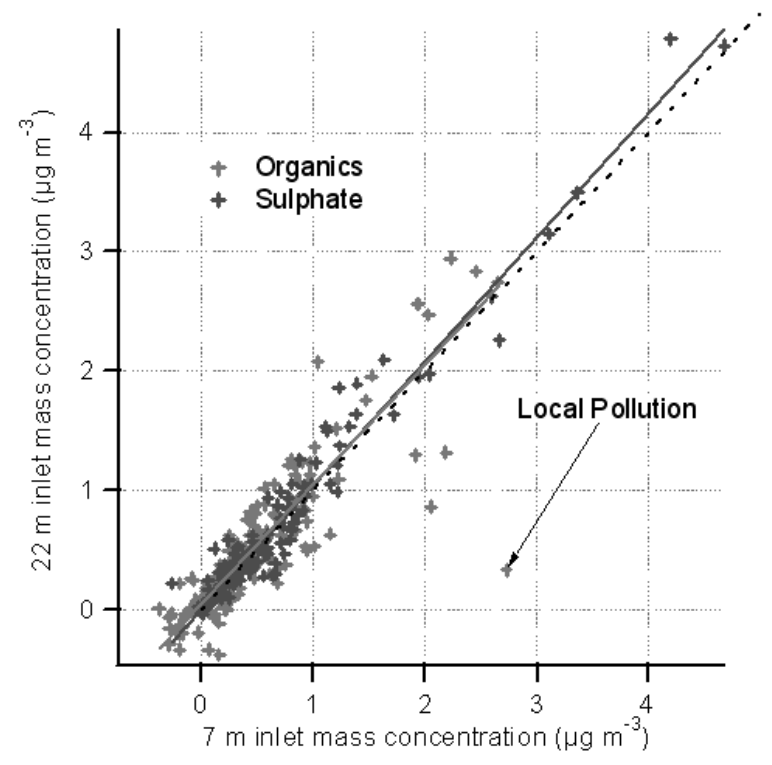

Fig. 4. Correlation between the submicron organic and sulphate mass loadings sampled through the $7 \mathrm{~m}$ and $22 \mathrm{~m}$ inlets. The data were sampled alternately through each inlet on an hourly basis and each data point represents a running average over three cycles.

concentration of diameter greater than $3 \mathrm{~nm}$, measured using the single CPC, sampled through the 7 and $22 \mathrm{~m}$ inlets. Minute average data were recorded and the inlet was switched hourly. The data in Fig. 3 are running averages calculated for each inlet over three full cycles. There are clearly periods when the number concentrations sampled by the two inlets do not agree, when the concentrations are large these are during the nucleation bursts and the average data from the DMPS (not shown) at the ultrafine sizes also show similar variability. At very low concentrations the relative changes can be large though the increase in total number small, as there are few particles during these very clean periods the relative variability also increases at timescales less than an hour and the scatter in the correlation increased. However, for much of the time the correlation is very strong and the gradient of unity shows that there are no significant diffusion losses down the sampling inlet. The size resolved data show that there is little evidence of systematic enhancement of particles at the $7 \mathrm{~m}$ sampling level, though, a few local sources of pollution enhance the Aitken mode concentration for brief periods at the $7 \mathrm{~m}$ level but not at $22 \mathrm{~m}$. Even particles in the 1 to $3 \mu \mathrm{m}$ range showed no evidence of the surface layer perturbing the concentration of particles at $7 \mathrm{~m}$ above ground level. Figure 4 shows a scatter plot of the submicron sulphate and organic mass as measured by the AMS at the 7 and $22 \mathrm{~m}$ level. There is no systematic difference in either the sulphate or the organic concentration sampled at the two levels. A few periods show the enhancement of organic mass at $7 \mathrm{~m}$, this correlates with the enhanced $50 \mathrm{~nm}$ particle number concen-

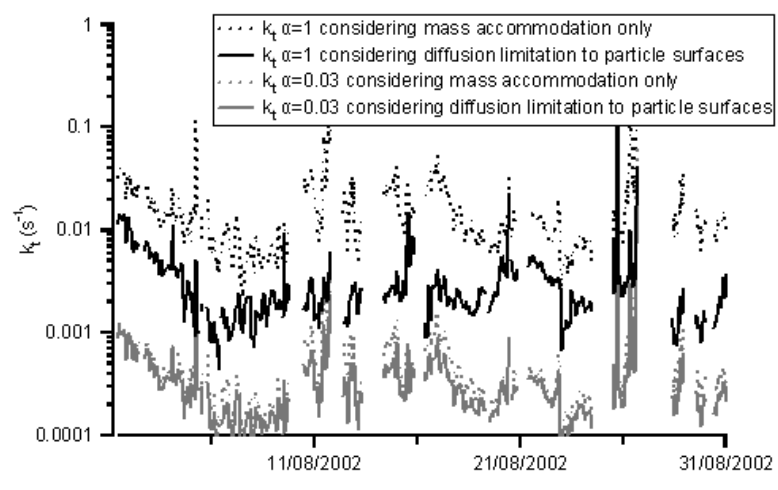

Fig. 5. Time series of uptake coefficients calculated using the expression provided by Schwartz (1986) (Eq. 3), considering diffusional limitation to mass transfer of gas to the particle surfaces compared to those assuming only a mass accommodation limitation (Eq. 1). Two different mass accommodation coefficients are shown to represent the mass accommodation limit, $\gamma=1$, and a value representative of a range of trace gases in the marine boundary layer, $\gamma=0.03$. Values of molecular diameter and molecular mass for HOI have been used to in the calculation of the binary diffusion coefficient.

tration. The mass spectra at the $7 \mathrm{~m}$ level, not shown, contain aliphatic fragmentation patterns similar to direct vehicle exhaust emissions and identify that these brief periods are due to local combustion sources. The aerosol population at Mace Head is little influenced by the coastal zone over much of its size range. The temporal and spatial variability of the ultrafine particles is known to be high (Hämeri et al., 2002) and clearly the averaging methodology used here will not capture this. However, outside these periods the total particle number, the submicron mass loading and the Aitken and accumulation modes and the smaller submicron particles sampled at $7 \mathrm{~m}$ or higher remain unaffected by the coastal zone.

\section{Diffusion limitations to mass transfer of trace gases to particle surfaces}

Aerosol particles provide a sink for many important trace gas and radical species in the marine boundary layer. McFiggans et al. (2002) have shown the importance of the loss of HOI onto deliquesced sea salt particle as a recycling route for reactive iodine in the catalytic removal of ozone in the marine boundary layer. Two of the major foci of the NAMBLEX experiment were the photochemistry of peroxy radicals and an assessment of the halogen cycle in the remote marine boundary layer Heard et al. 2005. In the marine environment accumulation and coarse mode particles provide the main surface area and the coarse mode the largest volume, so diffusional transfer limitations of species with high surface uptake rates are likely to be important. Here we present the method by which heterogeneous losses were calculated throughout 


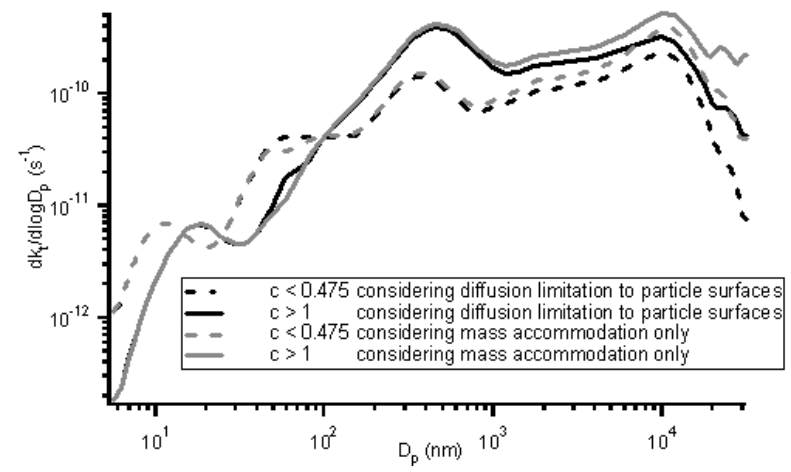

Fig. 6. Normalised size dependent uptake coefficients for clean and polluted conditions during NAMBLEX calculated considering diffusion limitation to the particle surface and compared with those assuming mass accommodation limitation only. An accommodation coefficient of 0.03 has been assumed and values of HOI were incorporated in the calculation of the binary diffusion coefficient.

the NAMBLEX experiment, demonstrate the importance of diffusion and surface uptake and summarise how these processes impact on species that are relevant to gas phase photochemistry in the marine environment, conditions relevant to the NAMBLEX study.

The loss rate of a gas phase species with uptake coefficient $\gamma$, is often taken to be:

$k_{t \gamma}=\frac{\bar{c}_{g} \gamma A}{4}$

where $A$ is the particle surface area and $\bar{c}_{g}$ is the average velocity of the gas molecules, given by:

$\bar{c}_{g}=\sqrt{\frac{8 k T}{\pi \bar{M}_{w}}}$

where $M_{w}$ is the molecular weight of the gas, $k$ is the Boltzmann constant and $T$ is the temperature.

However, expression (1) is only valid in the molecular regime where the mass accommodation dominates the overall loss. If the particles are considerably larger than the mean free path of the gas molecules, this no longer holds and the mass transfer to the particle surfaces must also be considered. Schwartz (1986) gives an expression for $k_{t \gamma}$ in the transition regime:

$k_{t \gamma}=\frac{4 \pi}{3} \int_{0}^{\infty}\left(\frac{r^{2}}{3 D_{g}}+\frac{4 r}{3 \bar{c}_{g} \gamma}\right)^{-1} r^{3} \frac{d N}{d \log r} d \log r$

where $r$ is the particle radius and $N$ is the number population of particles. The binary gaseous diffusion coefficient, $D_{g}$, is given by Maitland et al. (1981):

$D_{g}=\frac{3}{16 n_{\text {air }}} \sqrt{\left(\frac{2 k T}{\pi \bar{M}_{w}}\right)} \frac{1}{d_{\mathrm{ef}}^{2}}$

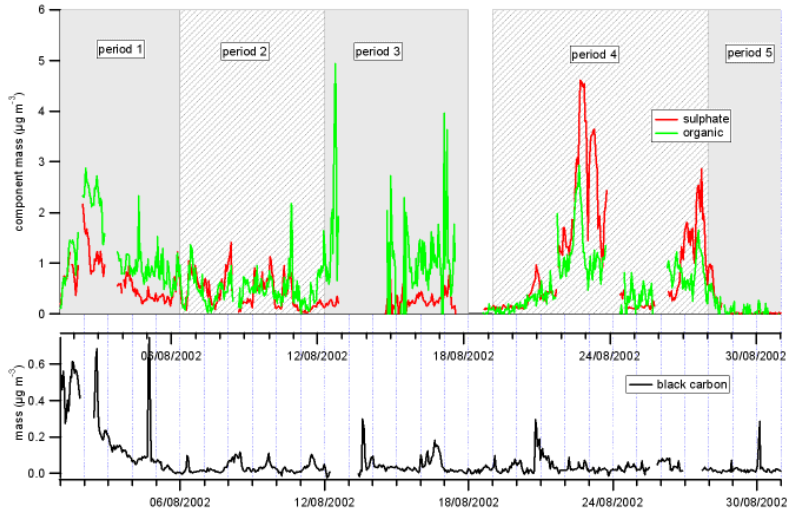

Fig. 7. Time series of the submicron organic and sulphate mass loadings as measured by the AMS during NAMBLEX. The five different meteorological periods are clearly marked. The bottom panel shows the black carbon mass concentrations derived from the aethelometer.

where $n_{\text {air }}$ is the concentration of air molecules at sea level, and $d_{\mathrm{ef}}$ is the effective collision diameter of the two molecules of the gas and air, given by the sum of their assumed radii. $\bar{M}_{w}$ is the reduced molecular weight or the ratio of the product to the sum of the molecular weights of the diffusing gas and air.

The derivation of expression (3) assumes that the transfer rates, calculated using the continuum regime in the droplet and the kinetic regime in the gas, are matched at the particle surface. This is not the case, however Sander (1999) has shown that differences between this and other flux-matching approximations such as that of Fuchs and Sutugin (1971), are mostly negligible and reach a maximum of $15 \%$ only when the ratio of the mean free path of the gas to the particle radius (the Knudsen number) and the accommodation coefficient approach unity, i.e. for small particles with high accommodation rates. These differences are small compared to the uncertainties in measurement of accommodation rates and hence the more straightforward expression above, that separates gas phase diffusion and surface accommodation rates, is used in this study.

The aerosol number size distributions presented in Sect. 3 have been used to show the variability of $\mathrm{k}_{\mathrm{t} \gamma}$ as a function of air mass history, windspeed, and aerosol size distribution and to show how the uptake is dependent on the uptake coefficient over a range of values that are typical of important molecules in the marine boundary layer. Figure 5 shows time series of the uptake coefficient, $k_{t \gamma}$ for the duration of the campaign with and without consideration of diffusional limitation to the particle surface and for two different values of $\gamma$, 0.03 and 1 . The former value is typical of many molecules in the marine boundary layer. An example is HOI, important in the iodine cycle in the marine boundary layer and the molecular mass of HOI is used in the calculation of the bi- 

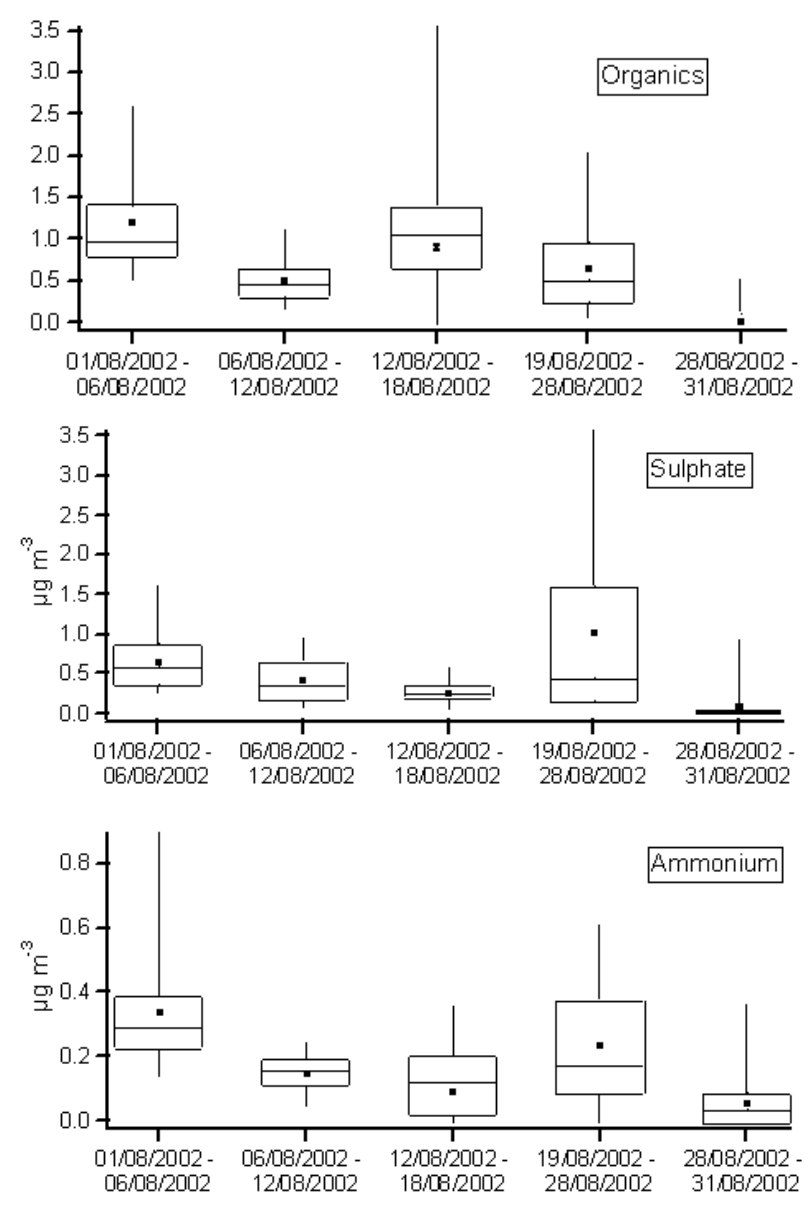

Fig. 8. The mean, median, and 10, 25, 75, and 90th percentiles of the submicron mass loadings of organic (a), sulphate (b) and ammonium (c) measured by the AMS during each of the five meteorological periods identified during the NAMBLEX experiment.

nary diffusion coefficient and average gas velocity in this example. The rate of diffusion to particle surfaces can be considered for other gases with similar $\gamma$ straightforwardly as both $D_{g}$ and $\bar{c}_{g}$ are to a large extent controlled by $1 / \sqrt{M_{w}}$. When $\gamma=1$ accommodation of the gas at the particle surface cannot be faster, providing the upper limit to surface transfer rate, whether by physical or chemical loss. Clearly, a large range of $k_{t y}$ values are observed during the course of the experimental period, considerably more than one order of magnitude variation is seen for either value of $\gamma$. This is typical of such an environment where the coarse mode particle loading is dictated to a large extent by the local windspeed and the pollution loadings of accumulation mode aerosol experienced are highly variable. In the accommodation limit, the lifetimes of the gas with respect to loss on particle surfaces are never less than $100 \mathrm{~s}$ and only in extreme wind conditions or during periods of significant aerosol loading does it fall below 200 s. For many gaseous species, such as HOI, their loss to particle surfaces is relative slow and lifetimes of between
$10^{3}$ and $10^{4} \mathrm{~s}$ are more typical for this route. (Fig. 5).

Figure 5 also shows the effects of not considering diffusional limitation of mass transfer to the surface. Several studies have attempted to close radical budgets using box models constrained by in situ measurements but many of these have only considered surface uptake of key species and not their diffusion to the surface. Here we demonstrate the systematic overestimates of loss in cases typical of the marine boundary layer. When $\gamma$ is of the order of 0.03 , diffusional limitations lead to an increase in the lifetime of the gas (in this case HOI) due to heterogeneous loss of around 50\% for most of the time during the NAMBLEX experiment. For higher values of $\gamma$ this effect increased so that in the mass accommodation limit the loss rate of a gas to the particle surface can be over-estimated by up to an order of magnitude.

The normalised size dependence of the uptake rate of a gaseous compound with an uptake coefficient of 0.03 , in this example HOI, is shown in Fig. 6 during the clean and polluted conditions observed during NAMBLEX. The accumulation and coarse modes contribute approximately equally to the heterogeneous loss rate on average during the NAMBLEX experiment in both the heavily polluted and clean conditions. Also shown are the corresponding size dependent uptake rates assuming accommodation limitation at the surface only. Uptake to submicron aerosol is unaffected by diffusion limitation to the particle surface and a consideration of mass accommodation alone is sufficient to correctly estimate loss of gaseous material to these particles. However, without consideration of the diffusion limitation uptake rates are overestimated by a factor two for coarse mode aerosol in this case. It should be borne in mind that if gases with larger accommodation coefficients are considered these arguments extend to smaller sized aerosol particles. Given that considerably higher coarse mode particle concentrations have been observed in the marine boundary layer than were present during NAMBLEX (O'Dowd et al., 2001) then it is to be expected that uptake rates are dominated by the coarse mode in many clean marine environments.

During the NAMBLEX experiment, the impact of heterogeneous loss on halogen cycling and $\mathrm{HO}_{\mathrm{x}}$ chemistry, was assessed in detail. HOI is important in recycling of iodine through aerosol in the marine boundary layer and it plays a role in the partitioning of $\mathrm{OH}$ and $\mathrm{HO}_{2}$, being formed from the $\mathrm{IO}$ reaction with $\mathrm{HO}_{2}$ and photolysing to form $\mathrm{OH}$ and I. Bloss et al. (2005) used the data presented here but with a $\gamma$ of 0.6 and showed that photolysis of HOI can account for $16 \%$ of the total $\mathrm{OH}$ production. However Mössinger and Cox (2001) obtained a $\gamma$ of 0.061 using a wetted wall flow tube, which as Bloss et al. (2005) point out would lead to an increase in this $\mathrm{OH}$ formation route of around $30 \%$. Furthermore these calculations show that the uptake of $\mathrm{HO}_{2}$ was also important in determining the $\mathrm{HO}_{\mathrm{x}}$ budget, being responsible for $20 \%$ of its removal.

Simultaneous measurements of $\mathrm{OH}$ and $\mathrm{HO}_{2}$ were made by laser induced fluorescence during NAMBLEX (Smith et 
al., 2006) and were used to show that steady state predictions of $\mathrm{HO}_{2}$ were too high. Heterogeneous loss rates of $\mathrm{HO}_{2}$ using the data described here were shown to reduce the steady state concentration by between 30 and $70 \%$ based on a $\gamma=1$. Sommariva et al. (2006) used photochemical box models to predict the measured $\mathrm{OH}$ and $\mathrm{HO}_{2}$ behaviour and, whilst the measured and modelled $\mathrm{OH}$ were in reasonably good agreement accounting for gas phase cycling only, $\mathrm{HO}_{2}$ was overestimated by a factor of 2 . Better agreement was seen when uptake coefficients for $\mathrm{HOI}, \mathrm{HOBr}$ and $\mathrm{HO}_{2}$ were all increased to close to unity. There are few available measurements of uptake coefficient of $\mathrm{HO}_{2}$ to salt solutions typical of the marine boundary layer. Thornton and Abbatt (2005) measured reactive uptake coefficients of $\mathrm{HO}_{2}$ to deliquesced sulphuric acid and ammonium sulphate particles and showed that the loss was not first order in $\mathrm{HO}_{2}$. They also estimate that at typical tropospheric concentrations of $\mathrm{HO}_{2}$ overall reaction probabilities with the aerosol types at room temperature would be much less than 0.01. Similar measurements of uptake to sea salt particles have not been published but as the uptake mechanism postulated by Thornton and Abbatt is highly $\mathrm{pH}$ dependent it is possible that different behaviour may well be observed. To determine to what extent heterogeneous loss processes can influence $\mathrm{HO}_{2}$ chemistry, laboratory measurements of the relevant uptake coefficients to key aerosol types are necessary. Furthermore, this work has shown that in future closure studies it is important to thoroughly chemically and physically characterise the aerosol.

\section{The chemical composition of aerosol at Mace Head during NAMBLEX}

Figure 7 shows the time trends of mass loadings of sulphate and organic material measured using the AMS during the NAMBLEX experiment. The five periods identified in Sect. 3 are marked. There is clearly much variability through the experiment with the highest loadings occurring during periods of decoupled (period 1) and anticyclonic (period 4) flow. Black carbon concentrations are also shown and highlight periods of polluted and clean air at the site. The organic and sulphate concentrations are in a broad sense correlated indicating that the organic material is derived from anthropogenic sources, though their relative abundances vary. However, during period 3 the organic concentration is larger than sulphate and not correlated with the latter. This may indicate a marine source, though the uncertainties during this period are large making interpretation during the baseline conditions difficult.

The average, median, quartile and 10th and 90th percentile values for sulphate, organic and ammonium are shown for each period in Fig. 8. Throughout the NAMBLEX experiment, the organic and sulphate mass loadings are greater than $0.5 \mu \mathrm{g} \mathrm{m}^{-3}$ for at least $75 \%$ of the time. As already discussed Mace Head experienced few periods of background condi- tions during NAMBLEX but these data serve to indicate the background level of pollution on the marine edge of western Europe. The exception to this is period 5 which was subject to significant precipitation and hence aerosol removal.

Average size distributions of organic, sulphate and nitrate aerosol mass are shown for polluted $\left(\mathrm{c}>1 \mathrm{Mm}^{-1}\right)$ and clean $\left(\mathrm{c}<0.475 \mathrm{Mm}^{-1}\right.$ ) periods over the campaign period. The average size distributions in the clean and polluted periods are similar in shape, though the former is larger in magnitude. The extension of the organic mode to smaller sizes is due to brief periods of near source pollution adding a separate mode similar to that observed at urban locations (Allan et al., 2003) and are not representative of a background aerosol distribution. Nevertheless around $0.5 \mu \mathrm{g} \mathrm{m}^{-3}$ of both sulphate and organic material are present in clean air during NAMBLEX. The modal peaks of the sulphate and organic are similar, implying that the two components are internally mixed, externally mixed particles with different densities would have different vacuum aerodynamic diameters and hence different modal centres.

There is a significant change in the average mass spectrum collected during the clean period and that collected during the polluted period (Fig. 9). The polluted period is more similar to the average mass spectra taken at the Jungfraujoch at an altitude of $3500 \mathrm{~m}$ in the Swiss Alps. The latter is representative of mass spectra obtained from a wide range of sites across the northern hemisphere and represents an aged pollution aerosol that is highly oxygenated and is dominated by the $\mathrm{CO}_{2}^{+}$ion at $m / z$ 44. Zhang et al. (2005) have used a modified principal components analysis to show that the dominant component mass spectrum in many cases is very similar to that shown in Fig. 9. The mass spectrum obtained in clean conditions is similar to that obtained in polluted conditions but differs in a number of ways. Most notably the ratio $\mathrm{m} / \mathrm{z}$ 44 to $\mathrm{m} / \mathrm{z}, 43$ is much lower than in the aged pollution mass spectrum and a peak at $m / z 56$ is present. This may well indicate a different chemical signature and/or source. Furthermore, the relative abundance of peaks between $\mathrm{m} / \mathrm{z}, 60$ and $m / z, 100$ is also greater in the clean conditions. This also indicates a different source. There is some evidence to suggest that the MS collected during the polluted period could be seen as a superposition of the Jungfraujoch MS and that from the clean period though there is insufficient data to statistically confirm this. Coarse mode particulate composition was measured during periods 3 and 4 only. As is to be expected the supermicron aerosol was dominated by sea salt. During period 3, the only significant period of background marine air experienced during the impactor sampling period, no significant depletion of chloride was observed. However, under the more polluted conditions during period 4 , the acid displacement of chloride can explain the attainment of charge balance (Fig. 10). Nitrate appeared to be the primary cause of the chloride displacement, contributing at least 3 times more than sulphate on a molar basis (not shown). The impactor analyses also show that the sulphate 

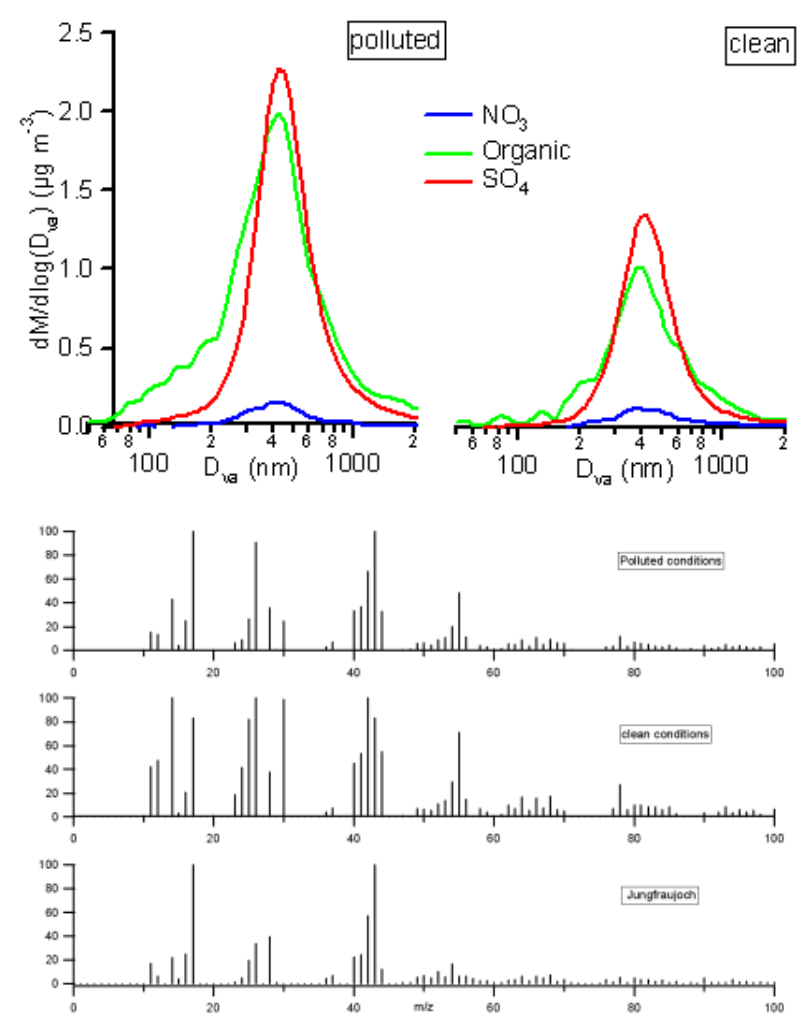

Fig. 9. Submicron average mass size distributions of organic, sulphate and nitrate measured using the AMS during polluted ( $c>$ $1 \mathrm{Mm}^{-1}$ ) and clean $\left(<0.475 \mathrm{Mm}^{-1}\right)$ (panel a). Also shown are the averaged organic mass spectra for the same two conditions during the NAMBLEX experiment. A mass spectrum taken using the same AMS at the Jungfraujoch is shown for comparison (panel b).

dominates in the fine mode throughout both sample periods, being an order of magnitude greater than chloride at particle aerodynamic diameters less than $600 \mathrm{~nm}$ and only comparable with the sulphate loading at larger sizes. The impactor analyses also show that the sulphate mass dominates in the fine mode throughout both sample periods, being an order of magnitude greater than chloride at particle aerodynamic diameters less than $600 \mathrm{~nm}$. The chloride loadings are only comparable with the sulphate loadings at larger sizes.

\section{$7 \quad$ Discussion and conclusions}

A characterisation of the physical and chemical composition of the ambient aerosol was conducted at the Mace Head Atmospheric Observatory on the west coast of Ireland during August 2002 as part of the NAMBLEX experiment. Iodocarbon and ultrafine particle measurements have shown that this site is influenced by the littoral zone at low tide. Here multi-height measurements of aerosol number and composi-

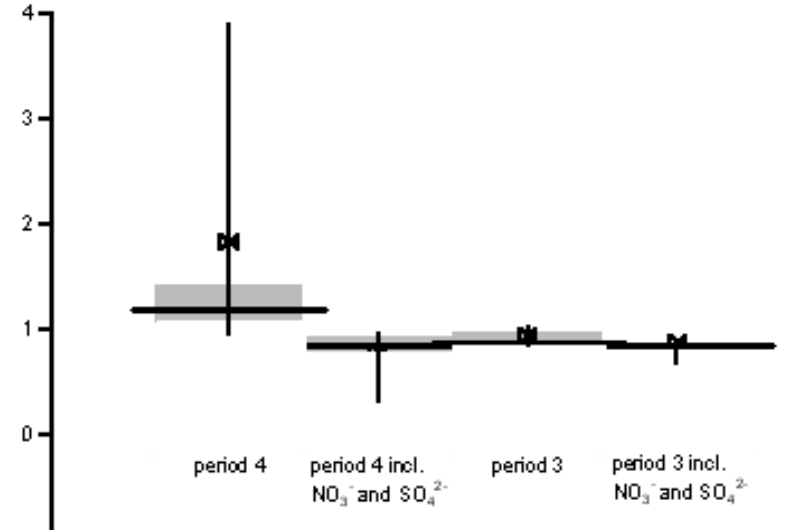

Fig. 10. Mean (bows), median (horizontal line), 25th and 75th percentiles (grey box) and 10th and 90th percentiles (black vertical line) of the supermicron $\mathrm{Na}: \mathrm{Cl}$ molar ratio for periods 3 and 4 . Also shown are the corresponding charge equivalent ratios accounting for displacement of chloride by nitrate and non sea salt sulphate. It is worth noting that $\mathrm{Na}: \mathrm{Cl}$ in sea salt is 0.86 .

tion show that Aitken and accumulation mode aerosol are not influenced by the coast under a wide range of conditions.

An assessment of the diffusion limitation to mass transfer of trace gases to particles was conducted. Gaseous uptake to submicron particle surfaces is dominated by mass accommodation at the surface, even for gases with accommodation coefficients that approach unity. However, the uptake rates of gases to coarse mode particles are significantly suppressed by gaseous diffusion limitations. Under the conditions observed during NAMBLEX such reductions in uptake rate can be as large as a factor of 5 for high accommodation rates and even a factor of 2 for accommodation coefficients of 0.03 , typical of a wide range of trace gases in marine boundary layers. Higher winds, generating significant sea spray, will most likely enhance this phenomenon.

The measurements of aerosol chemical composition show that there is often a significant semi ubiquitous background organic component of the submicron particle mass at Mace Head in a wide range of conditions with a mass loading of between 0.5 and $1 \mu \mathrm{g} \mathrm{m}^{-3}$ and there is often evidence of significant organic and sulphate mass in air masses transported over considerable distances. The organic mass fraction appears to have a mass spectral signature that is similar to other sites sampled with an AMS in the northern mid latitudes (Allan et al., 2003, 2004; Alfarra et al., 2004) during polluted conditions. The shape of the mass distributions of organic and sulphate are similar suggesting that the components are often internally mixed and hence indicate long range transportation. However, at times there is an increase in the organic mass at larger sizes that does not correlate with sulphate or other aged pollution markers. This is discussed further in Dall'Osto et al. (2005). There is little contribution 
of sea salt to the submicron aerosol, though it dominates the coarse mode. When exposed to polluted air the coarse mode aerosol shows evidence for chloride displacement that appears largely due to nitrate uptake.

O'Dowd et al. (2004) have shown that significant organic material is present in the submicron marine aerosol during clean conditions (identified by measured absorption coefficients below $0.475 \mathrm{Mm}^{-1}$ and wind directions between $180^{\circ}$ and $330^{\circ}$ ). They link the organic in the particles to that found in the organic material in the sea surface microlayer and postulate that sea spray generation through bubble bursting when a surfactant layer is present is likely to lead to submicron particles with a high organic content and little sea salt. The particles were observed to extend in size down to a hundred nanometres or less. Dall'Osto et al. (2005) identified Magnesium rich particles at Mace Head during high wind speeds in the clean air sector using a laser desorption-ionisation single particle time of flight mass spectrometer and showed that organic material is present in the same particles. Prather et al. ${ }^{2}$ were the first to identify $\mathrm{Mg}$ in particles combined with organic material and postulated that this arises from Magnesium contained in chlorophyll.

In this paper the mass spectral fingerprints of the organic fraction of the submicron aerosol as measured by the AMS under clean conditions show distinctly different fragmentation from the more polluted periods. These changes may well reflect the change in source, such as the primary surfactant organic formed from sea spray generation as postulated by O'Dowd et al. (2004). Dall'Osto et al. (2005) separated AMS size distributions that occurred during periods when $\mathrm{Mg}$-rich particles were observed from those measured during other periods. Although most of the organic mass was shown to have a similar size distribution to that of sulphate, indicating long range transported pollution similar to that observed in other periods, a second mode was observed in particles above $1000 \mathrm{~nm}$ diameter, extending beyond the $50 \%$ upper size cut off of the inlet lens. Mass spectral analysis of the periods when $\mathrm{Mg}$ was present and when it was not, do not show statistically significant differences with the AMS. However, the larger mode appeared at sizes that are transmitted very inefficiently by the AMS lens and therefore material in such particles is undersampled and does not contribute to the total measured particle ensemble mass spectra. It is difficult to establish whether the organic material in the mode seen at large particle sizes is the same as that observed by O'Dowd et al. (2004) as the ultra-clean conditions observed by O'Dowd et al. were not observed during NAMBLEX. Although the measured size distributions were different to those observed in O'Dowd et al., the ATOFMS has a strongly size dependent efficiency and simply may not have observed smaller particles of a similar composition. In addition, the AMS

\footnotetext{
${ }^{2}$ Prather, K., Guazzotti, S., and Holecek, C.: Probing atmospheric aerosol sources and processing using single particle mass spectrometry, in preparation.
}

only operated for a fraction of the available time in the clean conditions during NAMBLEX. Furthermore, the presence of a significant mixed sulphate-organic mass mode prevented causal differences being established from the AMS data set presented here as an unequivocal mass spectrum could not be obtained to identify a possible second source of organic material.

Though these results indicate that under clean conditions there may be a significant change in the mass spectral fingerprint of the organic fraction and this may give rise to size dependent changes in the organic aerosol size distribution there is at present insufficient data to draw causal relationships from the observations. Size dependent mass spectra collected over a longer time period in clean conditions would enable such relationships to be drawn. Such measurements are now possible using an AMS fitted with a Time of Flight Mass spectrometer (Drewnick et al., 2005) instead of the quadrupole. This instrument is capable of producing size resolved mass spectra with a much improved signal to noise ratio. The instrument is also capable of delivering complete mass spectra of individual particles, enabling the study of mixing states. This will in turn allow the direct observation of particles produced locally from the sea surface layer separately from the background aerosol. It is recommended that such a study is carried out to determine the variability and size distribution of the organic component of marine aerosol.

Acknowledgements. The authors would like to thank D. Heard and K. Read for their organization throughout the NAMBLEX project and to G. Spain and M. Geever for their valuable assistance during the experiment. The instrument deployment was supported through NERC Universities' Facility for Atmospheric Measurements (UFAM) and data analysis was supported by the NERC Distributed Institute for Atmospheric Composition (DIAC). The NAMBLEX experiment was supported by NERC through grant NER/A/S/2000/01393.

Edited by: D. Heard

\section{References}

Alfarra, M. R., Coe, H., Allan, J. D., Bower, K. N., Boudries, H., Canagaratna, M. R., Jimenez, J. L., Jayne, J. T., Garforth, A. A., Li, S. M., and Worsnop, D. R.: Characterization of urban and rural organic particulate in the Lower Fraser Valley using two Aerodyne aerosol mass spectrometers, Atmos. Environ., 38, 34, 5745-5758, 2004.

Allan, J. D., Jimenez, J. L., Williams, P. I., Alfarra, M. R., Bower, K. N., Jayne, J. T., Coe, H., and Worsnop, D. R.: Quantitative sampling using an Aerodyne aerosol mass spectrometer 1, Techniques of data interpretation and error analysis., J. Geophys. Res.-Atmos., 108, D3, 4090-4099, 2003.

Allan, J. D., Bower, K. N., Coe, H., Boudries, H., Jayne, J. T., Canagaratna, M. R., Millet, D. B., Goldstein, A. H., Quinn, P. K., Weber, R. J., and Worsnop, D. R.: Submicron aerosol composition at Trinidad Head, California, during ITCT 2K2: Its relationship 
with gas phase volatile organic carbon and assessment of instrument performance, J. Geophys. Res., 109, D23, 2004.

Baumgardner, D., Strapp, W., and Dye, J. E.: Evaluation of the Forward Scattering Spectrometer Probe - Part II: Corrections for coincidence and dead-time losses, J. Atmos. Oceanic Technol., 2, 626-632, 1985.

Bower, K. N., Jones, A., and Choularton, T. W.: A modelling study of aerosol processing by stratocumulus clouds and its impact on GCM parameterisations of cloud and aerosol., Atmos. Res., 50, 3-4, 317-344, 1999.

Bloss, W. J., Lee, J. D., Johnson, G. P., Sommariva, R., Heard, D. E., Saiz-Lopez, A., Plane, J. M. C., McFiggans, G., Coe, H., Flynn, M., Williams, P., Rickard, A. R., and Fleming, Z. L.: Impact of halogen monoxide chemistry upon boundary layer $\mathrm{OH}$ and $\mathrm{HO}_{2}$ concentrations at a coastal site., Geophys. Res. Lett., 32, 6, 2005.

Carslaw, N., Carpenter, L. J., Plane, J. M. C., Allan, B. J., Burgess, R. A., Clemitshaw, K. C., Coe, H., and Penkett, S. A.: Simultaneous observations of nitrate and peroxy radicals in the marine boundary layer, J. Geophys. Res., 102, D15, 18 917-18934, doi:10.1029/97JD00399, 1997.

Clarke, A. D, Uehara, T., and Porter, J. N.: Atmospheric nuclei and related fields over the Atlantic: clean subsiding air and continental pollution during ASTEX., J. Geophys. Res. 102, 25 281$25292,1997$.

Dall'Osto, M., Beddows, D. C. S., Kinnersley, R. P., Harrison, R. M., Donovan, R. J., and Heal, M. R.: Characterization of individual airborne particles by using aerosol time-of-flight mass spectrometry at Mace Head, Ireland., J. Geophys. Res., 109, D21302, doi:10.1029/2004JD004747, 2004.

Dall'Osto, M., Harrison, R. M., Furutani, H., Prather, K. A., Coe, H., and Allan, J. D.: Studies of aerosol at a coastal site using two aerosol Mass Spectrometry instruments and identification of biogenic particle types, Atmos. Chem. Phys. Discuss., 5, 10799 $10838,2005$.

de Gouw, J. A., Middlebrook, A. M., Warneke, C., Goldan, P. D., Kuster, W. C., Roberts, J. M., Fehsenfeld, F. C., Worsnop, D. R., Canagaratna, M. R., Pszenny, A. A. P., Keene, W. C., Marchewka, M., Bertman, S. B., and Bates, T. S.: Budget of organic carbon in a polluted atmosphere: Results from the New England Air Quality Study in 2002, J. Geophys. Res. 110, D16, Art. No. D16305, 2005.

de Leeuw, G., Kunz, G. J., Buzorius, G., and O’Dowd, C. D.: Meteorological influences on coastal new particle formation, J. Geophys. Res, 107, D19, 2002.

Dore, A. J., Johnson, D. W., Osborne, S. R., Choularton, T. W., Bower, K. N., Andreae, M. O., and Bandy, B. J.: Evolution of boundary-layer aerosol particles due to in-cloud chemical reactions during the 2nd Lagrangian Experiment of ACE-2, Tellus 52B, 452-462, 2000.

Drewnick, F., Hings, S. S., DeCarlo, P. F., Jayne, J. T., Gonin, M., Fuhrer, K., Weimer, S., Jimenez, J. L., Demerjian, K. L., Borrmann, S., and Worsnop, D. R.: A new time-of-flight aerosol mass spectrometer (ToF-AMS) - Instrument description and first field deployment., Aerosol Sci. Technol., 39, 637-658, 2005.

Fuchs, N. A. and Sutugin, A. G.: Highly dispersed aerosols, in Topics in Current Aerosol Research, edited by Hidy, G. M. and Brock, J. R., 2, 1-60, Pergamon, Oxford, 1971.

Geever, M., O’Dowd, C. D., van Ekeren, S., Flanagan, R., Nilsson, E. D., de Leeuw, G., and Rannik, U.: Submicron sea spray fluxes,
Geophys. Res. Lett., 32, 15, Art. No. L15810, 2005.

Grossart, H. P.: Interactions between marine bacteria and axenic diatoms (Cylindrotheca fusiformis, Nitzschia laevis, and Thalassiosira weissflogii) incubated under various conditions in the lab., Aquat. Microb. Ecol. 19, 1-11, 1999.

Haggerstone, A. L., Carpenter, L. J., Carslaw, N., and McFiggans G.: Improved model predictions of $\mathrm{HO}_{2}$ with gas to particle mass transfer rates calculated using aerosol number size distributions, J. Gepohys. Res., 110, D4, Art. No. D04304, 2005.

Hämeri, K., O'Dowd, C. D., and Hoell C.: Evaluating measurements of new particle concentrations, source rates, and spatial scales during coastal nucleation events using condensation particle counters, J. Geophys. Res., 107, D19, 8101, doi:10.1029/2001JD000411, 2002.

Heard, D. E., Read, K. A., Methven, J., et al.: The North Atlantic Marine boundary Laer Experiment (NAMBLEX), Overview of the campaign held at Mace Head, Ireland, in summer 2002, Atmos. Chem. Phys., 6, 2241-2272, 2006, http://www.atmos-chem-phys.net/6/2241/2006/.

Hoffman, E. J. and Duce, R. A.: The organic carbon content of marine aerosol collected on Bermuda, J. Geophys. Res. 79, 4474 4477, 1976.

Jayne, J. T., Leard, D. C., Zhang, X. F., Davidovits, P., Smith, K. A., Kolb, C. E., and Worsnop, D. R.: Develpoment of an aerosol mass spectrometer for size and composition analysis of submicron particles, Aeros. Sci. Tech., 33, 1, 49-70, 2000.

Jennings, S. G., Geever, M., McGovern, F. M., Francis, J., Spain, T. G., and Donaghy, T.: Microphysical and physico-chemical charaterization of atmospheric marine aerosol at Mace Head., Atmos. Environ., 31, 17, 2795-2808, 1997.

Jimenez, J. L., Jayne, J. T., Shi Q. et al.: Ambient aerosol sampling using the Aerodyne Aerosol Mass Spectrometer, J. Geophys. Res, 108, D7, 8425-8437, 2003.

Kunz, G. J., de Leeuw, G., Becker, E., and ODowd, C. D.: Lidar observations of atmospheric boundary layer structure and sea spray aerosol plumes generation and transport at Mace Head, Ireland (PARFORCE experiment), J. Geophys. Res., 107, D19, 2002.

Larsson, U. and Hagström, Å.: Fractionated phytoplankton primary production, exudate release and bacterial production in a baltic eutrophication gradient, Marine Biology 67, 57-70, 1982.

Maitland, G. C. et al.: Intermolecular forces: their origin and determination, International series of monographs on chemistry 3 , Oxford, Clarendon Press, 1981.

McFiggans, G., Cox, R. A., Mossinger, J. C., Allan, B. J., and Plane, J. M. C.: Active chlorine release from marine aerosols: Roles for reactive iodine and nitrogen species., J. Geophys. Res., 101, D15, 2002.

McFiggans, G., Coe, H, Burgess, R. Allan, J., Cubison, M., Alfarra, M. R., Saunders, R., Saiz-Lopes, A., Plane, J. M. C. P., Wevill, D. J., Carpenter, L. J., Rickard, A. R., and Monks, P. S.: Direct evidence for coastal iodine particles from Laminaria macroalgae - linkage to emissions of molecular iodine, Atmos. Chem. Phys., 4, 701-713, 2004, http://www.atmos-chem-phys.net/4/701/2004/.

Mössinger, J. C. and Cox, R. A.: Heterogeneous reaction of HOI with sodium halide salts, J. Phys. Chem. A, 105, 5165-5177, 2001.

Nilsson, E. D., Rannik, U., Swietlicki, E., Leck, C., Aalto, P. P., Zhou, J., and Norman, M.: Turbulent aerosol fluxes over the 
Arctic Ocean 2. Wind-driven sources from the sea, J. Geophys. Res.-Atmos., 106, D23, 32 139-32 154, 2001.

Norton, E. G., Vaughan, G., Methven, J., Coe, H., Brooks, B., Gallagher, M, and Longley, I.: Boundary layer structure and decoupling from synoptic scale flow during NAMBLEX, Atmos. Chem. Phys., 6, 433-445, 2006, http://www.atmos-chem-phys.net/6/433/2006/

O'Dowd, C. D., Smith, M. H., Consterdine, I. E., and Lowe, J. A.: Marine aerosol, sea-salt and the marine sulphur cycle: a short review, Atmos. Environ., 31, 73-80, 1997.

O’Dowd, C., McFiggans, G., Creasey, D. J., Pirjola, L., Hoell, C., Smith, M. H., Allan, B. J., Plane, J. M. C., Heard, D. E., Lee, J. D., Pilling, M. J., and Kulmala, M.: On the photochemical production of new particles in the coastal boundary layer, Geophys. Res. Lett., 26, 12, 1707-1710, 1999.

O’Dowd, C. D., Becker, E., and Kulmala, M.: Mid-latitude NorthAtlantic aerosol charateristics in clean and polluted air, Atmos. Res., 58, 167-185, 2001.

O’Dowd, C. D., Hämeri, K., Mäkelä, J., Vakeva, M., Aalto, P., de Leeu w, G., Kunz, G. J., Becker E., Hansson, H. C., Allen, A. G., Harrison, R. M., Berresheim, H., Geever, M., Jennings, S. G., and Kulmala, M.: Coastal new particle formation: Environmental conditions and aerosol physicochemical characteristics during nucleation bursts, J. Geophys. Res., 107, D19, 2002.

O’Dowd, C. D., Hämeri, K., Mäkelä, J. M., Kulmala, M., Pirjola, L., Berresheim, H., Jennings, S. G., Hansson, H.-C., de Leeuw, G., Allen, A. G., Hewitt, C. N., Stroh, A., and Viisanen, Y.: A dedicated study of new particle formation and fate in the coastal environment (PARFORCE): Overview of objectives and initial achievements., J. Geophys. Res., 107, D19, 2002.

O’Dowd, C. D., Facchini, M. C., Cavalli, F., Ceburnis, D., Mircea, M., Decesari, S., Fuzzi, S., Yoon, Y. J., Putaud, J. P.: Biogenically driven organic contribution to marine aerosol., Nature, 431, 7009, 676-680, 2004.

Quinn, P. K., Kapustin, V. N., Bates, T. S., and Covert, D. S.: Chemical and optical properties of marine boundary layer aerosol particles of the mid-Pacific in relation to sources and meteorological transport, J. Geophys. Res.-Atmos., 101, 6931-6951, 1996.

Raes, F.: Entrainment of free tropospheric aerosols as a regulating mechanism for cloud condensation nuclei in the remote marine boundary-layer, J. Geophys. Res.-Atmos., 100, D2, 2893-2903, 1995.

Sander, R.: Modelling atmospheric chemistry: interactions betweengas-phase species and liquid cloud/aersol particles, Surveys in Geophysics, 20,1-31, 1999.

Saiz-Lopez, A., Plane, J. M. C., McFiggans, G., Williams, P. I., Ball, S. M., Bitter, M., Jones, R. L., Hongwei, C., and Hoffmann, T.: Modelling molecular iodine emissions in a coastal marine environment: the link to new particle formation, Atmos. Chem. Phys., 6, 883-895, 2006, http://www.atmos-chem-phys.net/6/883/2006/.
Saiz-Lopez, A., Shillito, J. A., Coe, H., and Plane, J. M. C.: Measurements and modelling of $\mathrm{I}_{2}, \mathrm{I}_{\mathrm{O}}, \mathrm{O}_{\mathrm{I}} \mathrm{O}, \mathrm{Br}_{\mathrm{O}}$ and $\mathrm{NO}_{3}$ in the mid-latitude marine boundary layer, Atmos. Chem. Phys., 6, 1513-1528, 2006 http://www.atmos-chem-phys.net/6/1513/2006/.

Schwartz, S. E.: Mass-transport considerations pertinent to aqueous phase reactions of gases in liquid-water clouds, in Chemistry of Multiphase Atmospheric Systems, NATO ASI Series, G6, Jaeschke ed., Springer-Verlag, Berlin, 415-471, 1986.

Smith, S. C., Lee, J. D., Bloss W. J., Johnson, G. P., Ingham, T., and Heard, D. E.: Concentrations of $\mathrm{OH}$ and $\mathrm{HO} 2$ radicals during NAMBLEX: measurements and steady state analysis., Atmos. Chem. Phys., 6, 1435-1453, 2006 , http://www.atmos-chem-phys.net/6/1435/2006/.

Sommariva, R., Bloss W. J., Brough, N., Carslaw, N., Flynn, M., Haggerstone, A.-L., Heard, D. E., Hopkins, J. R., Lee, J. D., Lewis, A. C., McFiggans, G., Monks, P. S., Penkett, S. A., Pilling, M. J., Plane, J. M. C., Read, K. A., Saiz-Lopez, A., Rickard, A. R., and Williams, P. I.: $\mathrm{OH}$ and $\mathrm{HO}_{2}$ chemistry during NAMBLEX: roles of oxygenates, halogen oxides and heterogeneous uptake, Atmos. Chem. Phys., 6, 1135-1153, 2006, http://www.atmos-chem-phys.net/6/1135/2006/.

Thornton, J. and Abbatt, J. P. D.: Measurements of $\mathrm{HO}_{2}$ uptake to aqueous aerosol: Mass accommodation coefficients and net reactive loss., J. Geophys. Res.-Atmos., 110, D08309, doi:10.1029/2004JD005402, 2005.

Van Dingenen, R., Raes, F., and Jensen, N. R.: Evidence for anthropogenic input on number concentration and sulfate content of cloud processed aerosol particles over the North Atlantic, J. Geophys. Res.-Atmos., 100, 21 057-21 067, 1995.

Williams, P. I. W.: Construction and validation of a DMPS for aerosol charaterization, $\mathrm{PhD}$ Thesis, University of Manchester Institute of Science and Technology, 1999.

Williams, P. I., Gallagher, M. W., Choularton, T. W., Coe, H., Bower, K. N., and McFiggans, G.: Aerosol development and interaction in an urban plume, Aerosol. Sci. Technol., 32, 120-126, 2000.

Winklmayr, W., Reischl, G. P., Lindner, A. O., and Berner, A.: A new electromobility spectrometer for the measurement of aerosol size distributions in the size range from 1 to $1000 \mathrm{~nm}$, J. Aerosol Sci., 22, 3, 289-296, 1991

Zhang, Q., Alfarra, M. R., Worsnop, D. R., Allan, J. D., Coe, H., Canagaratna, M. R., and Jimenez, J. L.: Deconvolution and quantification of hydrocarbon-like and oxygentated aerosols based on aerosol mass spectrometry, Env. Sci. Technol. 39, 4938-4952, 2005. 